\title{
PENGARUH BAURAN PROMOSI TERHADAP MINAT MEMILIH PRODI MANAJEMEN FAKULTAS EKONOMI DAN BISNIS UMSURABAYA TAHUN 2017

\author{
Siti Salbiyah ${ }^{1}$, Budi Wahyu Mahardhika ${ }^{2}$
} \\ Prodi Manajemen Fakultas Ekonomi dan Bisnis Universitas Muhammadiyah Surabaya J1. Sutorejo No. 59 Surabaya 60113.Telp. (031)3811966-3811967 Fax.(031)3813096
}

\begin{abstract}
The success of an institution of higher education is inseparable from the marketing strategy undertaken. Promotion is one of the most important marketing strategies to introduce an educational product or service, in this case are various courses to prospective students. Promotion is done to generate interest in choosing the study program that becomes the choice of pride, so it will affect the increasing number of students each course offered. UMSurabaya through promotional mix (promotional mix) offers as many as 29 courses from 8 faculties owned, one of them is Management program as an alternative choice for prospective students.

This study aims to: (1) Know the promotion mix UMSurabaya. (2) To know the interest of choosing Management FEB UMSurabaya. (3) Knowing the promotion mix simultaneously affect the interest of choosing Management FEB UMSurabaya (4). Knowing the promotion mix partially affect the interest of choosing Management FEB UMSurabaya.

This research uses quantitative descriptive method with questionnaire as its instrument. Population amounted to 328 students using Slovin method specified sample of 77 respondents. Data analyze using SPSS 20 software to test the validity and reliability of the instrument, and test the hypothesis.

The results showed: (1) F test results obtained F-count $(9,184)>$ F-table $(2.47)$ which means that the promotion mix (advertising, direct selling, sales promotion, and community relations) simultaneously have a significant positive effect to the student's interest in choosing Management FEB UMSurabaya. Determinant coefficient analysis $\left(\mathrm{R}^{2}\right)$ obtained by value 33,8 indicates that student interest choose Management FEB UMSurabaya influenced by independent variable (advertising, direct selling, sales promotion and public relation) to dependent variable of interest to choose Management program 33,8\%, while the remaining $66.2 \%$ is influenced by other variable factors not mentioned in this study. 2 ). The result of $t$ test for advertising variable is $t$ value $(2,865)>t$-table $(1,984)$, this means that advertising variable has a significant positive effect on the interest of choosing Management FEB UMSurabaya. While the direct selling variables, sales promotion and public relations value $\mathrm{t}$-count in a row $(1,085),(1,521),(0,465)<\mathrm{t}$-table $(1,984)$, can be interpreted that the direct sales variables, sales promotion and public relations positively not significant to the interest in choosing FEB UMSurabaya Management Program. Thus,
\end{abstract}


advertising has the most dominant influence on the interest of choosing Management FEB UMSurabaya.

The authors conclude (1) Characteristics of UMSurabaya Management Study Program students are known to be $58 \%$ female and the rest are male students with average age between 20 - 25 years with parent / guardian's income level between Rp.1.000.000, - Rp. 4,000,000, - per month and most students come from Surabaya (2). UMSurabaya promotional mix has been effectively implemented in accordance with the information required by the students. Advertising is the most dominant promotional mix affecting the interest of choosing Management FEB UMSurabaya. Therefore, if UMSurabaya want to increase the number of students Management program, then the advertising activities should be enhanced more attractive.

Keywords : Promotional mix, Choosing Interests.

Correspondence to : sitisalbiyah51@gmail.com, budi.w.mahardhika@gmail.com

\begin{abstract}
ABSTRAK
Kesukesan suatu lembaga pendidikan tinggi tidak terlepas dari strategi pemasaran yang dilakukan. Promosi merupakan salah satu strategi pemasaran yang sangat penting untuk mempekenalkan suatu produk atau jasa pendidikan dalam hal ini adalah berbagai program studi kepada calon mahasiswa. Promosi dilakukan untuk menimbulkan minat memilih program studi yang menjadi pilihan kebanggaannya, sehingga akan berpengaruh kepada meningkatnya jumlah mahasiswa setiap program studi yang ditawarkan. UMSurabaya melalui bauran promosi (promotional mix) menawarkan sebanyak 29 program studi dari 8 fakultas yang dimiliki, salah satunya prodi Manajemen sebagai alternatif pilihan bagi calon mahasiswanya.

Penelitian ini bertujuan untuk: (1) Mengetahui bauran promosi UMSurabaya. (2) Mengetahui minat memilih prodi Manajemen FEB UMSurabaya. (3) Mengetahui bauran promosi secara simultan berpengaruh terhadap minat memilih prodi Manajemen FEB UMSurabaya (4). Mengetahui bauran promosi secara parsial berpengaruh terhadap minat memilih prodi Manajemen FEB UMSurabaya.

Penelitian ini menggunakan metode deskriptif dan kuantitatif dengan kuesioner sebagai instrumennya. Populasi berjumlah 328 mahasiswa dengan menggunakan metode Slovin ditetapkan sampel sebanyak 77 responden. Analisis data menggunakan software SPSS 20 untuk menguji validitas dan reliabilitas instrumen, serta menguji hipotesis.

Hasil penelitian menunjukkan : (1) Hasil Uji F diperoleh nilai F-hitung $(9,184)>$ Ftabel $(2,47)$ yang berarti bahwa bauran promosi(periklanan, penjualan langsung, promosi penjualan, dan hubungan masyarakat) secara simultan berpengaruh positif signifikan terhadap minat mahasiswa memilih prodi Manajemen FEB UMSurabaya. Analisis koefisien determinan $\left(\mathrm{R}^{2}\right)$ diperoleh nilai 33,8 menunjukkan bahwa minat mahasiswa memilih prodi Manajemen FEB UMSurabaya dipengaruhi oleh variabel bebas ( periklanan, penjualan langsung, promosi penjualan dan hubungan masyarakat ) terhadap variabel dependen minat memilih prodi Manajemen sebesar 33,8\%, sedangkan sisanya $66,2 \%$ dipengaruhi oleh faktor-faktor variabel lain yang tidak disebutkan dalam penelitian
\end{abstract}


ini.2). Hasil uji $\mathrm{t}$ untuk variabel periklanan diperoleh nilai $\mathrm{t}$-hitung $(2.865)>\mathrm{t}$-tabel $(1,984)$, ini berarti variabel periklanan memiliki pengaruh positif signifikan terhadap minat memilih prodi Manajemen FEBUMSurabaya. Sedangkan variabel penjualan langsung, promosi penjualan dan hubungan masyarakat nilai t-hitung berturut-turut $(1,085)$, $(1,521),(0,465)<\mathrm{t}$-tabel $(1,984)$, dapat diartikan bahwa variabel penjualan langsung, promosi penjualan dan hubungan masyarakat berpengaruh positif tidak signifikan terhadap minat memilih prodi Manajemen FEB UMSurabaya. Dengan demikian periklanan berpengaruh paling dominan terhadap minat memilih prodi Manajemen FEB UMSurabaya.

Penulis menyimpulkan (1) Karakteristik mahasiswa prodi Manajemen UMSurabaya diketahui $58 \%$ berjenis kelamin perempuan dan sisanya adalah mahasiswa berjenis kelamin laki-laki yang di dominasi oleh usia antara 20 - 25 tahun dengan tingkat pendapatan orang tua/wali antara Rp.1.000.000,- - Rp. 4.000.000,- per bulan dan 73\% mahasiswa berasal dari kota Surabaya (2). Bauran promosi UMSurabaya telah dilaksakanan secara efektif sesuai dengan informasi yang dibutuhkan para mahasiswa. Advertising merupakan bauran promosi yang paling dominan berpengaruh terhadap minat memilih prodi Manajemen FEB UMSurabaya. Oleh karena itu jika UMSurabaya ingin meningkatkan jumlah mahasiswa prodi Manajemen, maka kegiatan advertising harus ditingkatkan lebih atraktif lagi.
Kata kunci
: Promotional mix, Minat Memilih.
Korespondensi
: sitisalbiyah51@gmail.com, budi.w.mahardhika@gmail.com

\section{PENDAHULUAN / INTRODUCTION}

Pendidikan memegang peranan penting dalam semua aspek kehidupan manusia. Pendidikan merupakan alat yang paling efektif untuk meningkatkan kualitas individu supaya lebih produktif, selain itu pendidikan juga bertugas sebagai fungsi pengendali sosial, pengembangan tenaga kerja dan pembentukan sikap. Pendidikan dapat diperoleh dari berbagai lembaga pendidikan baik formal maupun non formal.

Dewasa ini, persaingan antar lembaga pendidikan formal khususnya perguruan tinggi di kota Surabaya semakin atraktif. Hal ini dapat dibuktikan dengan adanya berbagai upaya kreatif dan inovatif dari para penyelenggara pendidikan untuk terus menggali keunikan dan keunggulan kampusnya agar semakin dibutuhkan dan diminati oleh para pengguna jasa pendidikan dalam hal ini adalah peserta didik (mahasiswa). Masuknya perguruan tinggi unggulan dengan mutu pendidikan bertaraf internasional yang menawarkan beranekaragam keunggulan fasilitas, bahkan dengan biaya yang relatif terjangkau, akan menambah maraknya persaingan di dalam dunia pendidikan. Kegiatan pemasaran dan promosi di dalam dunia pendidikan yang dulu dianggap tabu sekarang sudah dilakukan terbuka dan terang-terangan. Perguruan tinggi sebagai lembaga penyedian jasa pendidikan perlu belajar dan memiliki inisiatif untuk meningkatkan kepuasan para pengguna jasa di bidang pendidikan karena pendidikan merupakan proses saling mempengaruhi dan berkelanjutan. Upaya perguruan tinggi untuk menarik input yang mampu berkopentensi (calon mahasiswa potensial) telah menjadi tuntutan yang wajib dipenuhi dalam rangka mendukung proses pembelajaran serta 
meningkatkan daya saing antar perguruan tinggi.

Munculnya perguruan tinggi negeri dan swasta akan berdampak terhadap persaingan yang semakin ketat dalam pengelolaan lembaga pendidikan tersebut. Berbagai cara ditempuh oleh banyak perguruan tinggi untuk memenangkan kompetisi antar perguruan tinggi serta untuk meningkatkan kualitas dan profesionalisme manajemen perguruan tinggi, begitu pula yang dilakukan oleh Universitas Muhammadiyah Surabaya yang selanjutnya disebut UMSurabaya guna meningkatkan kualitas jasa pendidikan yang ditawarkan kepada pengguna jasa pendidikan.

Untuk tetap bertahan di tengah ketatnya persaingan, maka sebuah perguruan tinggi tidak hanya sekedar mengembangkan program studi yang baik dan penawaran biaya yang bersaing, tetapi juga perlu memiliki kemampuan berkomunikasi dengan para pelanggan, masyarakat umum dan pihakpihak lain yang memiliki kepentingan dengan perguruan tinggi. Informasi itu sangat penting dalam pemasaran, agar setiap pihak yang berkepentingan mengerti maksud dari usaha yang atau program studi yang ditawarkan. Oleh karena itu dalam penyampaian informasi tersebut diperlukan adanya suatu kegiatan komunikasi yang efektif atau bisa disebut promosi.

Menurut Ratnasari R.T dan Aksa M.H ( 2011:41) promosi adalah bauran promosi (promotional mix) yang terdiri atas: (1) advertising, (2) personal selling, (3) sales promotion, (4) public relation, (5) word of mouth, dan (6) direct mail marketer dapat memilih sarana yang dianggap sesuai untuk mempromosikan jasa mereka.

Tjiptono F (2011:41) promotion. Bauran promosi tradisional meliputi berbagai metode untuk mengkomunikasikan manfaat jasa kepada pelanggan potensial dan aktual. Metode-metode tersebut terdiri atas periklanan, promosi penjualan, direct marketing, personal selling, dan public relations.

Promosi bukan saja berfungsi sebagai alat komunikasi antara perusahaan dengan pelanggan, melainkan juga sebagai alat untuk mempengaruhi pelanggan. Agar semua sarana tersebut terkordinir secara efektif, penetapan sasaran komunikasi dengan cermat sangat diperlukan. Komponen ini sangat penting dilakukan agar para stakeholdersakan mengerti dan mengetahui tentang keunggulan dan keistimewaan program studi itu, sehingga para pengguna jasa pendidikan tertarik memakai jasa tersebut dan mempengaruhi volume pemakaian jasa yang pada akhirnya akan meningkatkan minat masuk perguruan tinggi atas program studi yang ditawarkan. UMSurabayasebagai mitra pemerintah yang bergerak di bidang pendidikan, bertekad untuk ikut berpartisipasi dalam penyediaan sumber daya manusia yang handal, profesional dan memiliki daya saing di bidangnya. UMSurabaya melalui LIPMB (Lembaga Informasi Penerimaan Mahasiswa Baru) telah melakukan bauran promosi dalam meningkatkan jumlah mahasiswa baru pada setiap program studinya.

Berdasarkan keputusan BAN-PT No. 0455/SK/BAN-PT/Akred/S/I/2017, program studi Manajemen pada program sarjana UMSurabaya terakreditasi dengan peringkat B dan berlaku selama 5 tahun terhitung mulai 26 Januari 2017 sampai dengan 26 Januari 2022. Demikian juga visi yang dicanangkan oleh FEB UMSurabaya Surabaya yaitu "Prodi Manajemen FEB UMSurabaya menjadi program studi yang unggul di bidang manajemen, menjunjung tinggi moralitas dan berjiwa interpreneur".

Untuk menjaga mutu dan citra jasa pendidikan di tengah ketatnya persaingan yang datang dari pesaing, UMSurabaya perlu melakukan komunikasi efektif, yaitu bauran promosi(promotional mix) dari berbagai program studi termasuk program studi Manajemen, maka dilakukan penelitian yang berjudul " Pengaruh promotional mix terhadap minat memilih prodi Manajemen FEB UMSurabaya.

\section{TUJUAN PENELITIAN}

1. Mengetahui bauran promosi UMSurabaya.

2. Mengetahui minat memilih prodi Manajemen FEB UMSurabaya. 
3. Mengetahui bauran promosi secara simultan berpengaruh terhadap minat memilih prodi Manajemen FEB UMSurabaya

4. Mengetahui bauran promosi secara parsial berpengaruh terhadap minat memilih prodi Manajemen FEB UMSurabaya.

\section{METODE PENELITIAN / METHODS}

Penelitian ini menggunakan metode deskriptif kuantitatif. Sumber data yang digunakan adalah data primer yang diperoleh melalui penyebaran kuesioner kepada responden dan wawancara langsung dengan Tim LIPMB UMSurabaya.

Populasi dalam penelitian ini adalah seluruh mahasiswa prodi S1 Manajemen UMSurabaya sebanyak 328 mahasiswa pada saat penelitian ini dilakukan. Sampel penelitian ini ditentukan sebanyak 77 responden. Ukuran ini adalah hasil pembulatan angka 76,63551 responden yang di dapatkan dari rumus : Slovin dalam Riadi (2015:41)

$$
\begin{gathered}
\mathrm{n}= \\
\text { orang } \\
\mathrm{N}(\mathrm{d}) 2+1
\end{gathered}
$$

Keterangan :

$\mathrm{n}=$ Jumlah sampel

$\mathrm{N}=$ Jumlah populasi $=328$ orang

$\mathrm{d}=$ Presisi ( ditetapkan 10\% dengan tingkat kepercayaan $90 \%$ )

Pengumpulan data dilakukan dengan metode distribusi langsung yaitu mendatangi responden secara langsung untuk menyerahkan ataupun mengumpulkan kembali kuesioner.

Adapun hipotesisnya sebagai berikut:

1. Bauran promosi (periklanan, penjualan langsung, promosi penjualan dan hubungan masyarakat) secara simultan berpengaruh signifikan terhadap minat memilih prodi Manajemen FEB UMSurabaya.
2. Periklananberpengaruh paling dominan terhadap minat memilih prodi Manajemen FEB UMSurabaya.

Analisis data menggunakan software SPSS versi 18, 2016 dengan 5 lima tahapan; pertama analisis deskriptif, kedua pengujiann validitas dan reliabilitas instrumen, ketiga pengujian normalitas data, keempat analisis regresi linier berganda dan kelima pengujian hipotesis.

\section{KAJIAN TEORI}

1. Bauran Promosi(Promotional Mix)

Bauran promosi merupakan alat yang paling efektif untuk berkomunikasi dengan pelanggan (baik konsumen maupun perantara). Menurut American Marketing Association dalam Wijaya (2012:164), variabel-variabel bauran promosi ada empat kelompok, sebagai berikut:

a. Periklanan (advertising), yaitu bentuk presentasi dan promosi bukan pribadi tentang ide, produk dan jasa yang dibayar oleh sponsor tertentu.

Adapun dalam jasa pendidikan, "Periklanan yaitu bentuk-bentuk komunikasi bukan pribadi yang dilakukan pemasar jasa pendidikan, yang meliputi siaran radio (broadcast), materi tercetak (print), internet, papan reklame (Outdoor advertising) dan surat langsung (direct mail)" (Wijaya 2012:165).

b. Penjualan pribadi (personal selling), yaitu presentasi lisan dalam bentuk percakapan dengan satu orang calon pembeli atau lebih yang ditujukan untuk menciptakan penjualan.

Dalam pemasaran jasa pendidikan, penjualan pribadi bisa disebut dengan komunikasi pribadi, yaitu "Komunikasi secara langsung antara pemasar jasa pendidikan dan pelanggan jasa pendidikan yang melibatkan dialog dua arah, seperti percakapan tatap muka, panggilan tilpun dan surat elektronik" (Wijaya 2012:164).

c. Publisitas (publicity) yaitu upaya menimbulkan permintaan bukan 
secara pribadi pada produk, jasa, atau ide dengan menggunakan berita komersial di media massa dan sponsor yang tidak dibebankan sejumlah pembayaran secara langsung.

Adapun dalam jasa pendidikan untuk memicu minat positif terhadap sekolah dan produk jasa pendidikan melalui penyebaran berita baru, membuat konverensi pers, menyelenggarakan peristiwa istimewa dan mendanai aktivitas yang patut dijadikan berita oleh pihak ketiga sekolah" (Wijaya 2012:165)

d. Promosi penjualan (salles promotion), yaitu aktivitas penjualan selain penjualan pribadi, periklanan dan publisitas yang mendorong pembelian konsumen dan efektivitas peritel dalam bentuk peragaan, pertunjukan, pameran, demonstrasi dan sebagainya.

Dalam jasa pendidikan "Promosi penjualan yaitu bentuk insentif jangka pendek yang ditawarkan kepada pelanggan jasa pendidikan dan perantara jasa pendidikan untuk merangsang pembelian produk jasa pendidikan, kupon (coupon) produk jasa pendidikan, diskon (discout) produk jasa pendidikan, hadiah (gift) dan promosi berhadiah (prize promotion)" (Wijaya 2012: 165).

Untuk membangun sebuah perusahaan yang efektif, suatu perusahaan menggunakan variabelvariabel bauran promosi (promotional mix) yang telah disebutkan di atas baik produk barang atau jasa. Promosi yang dilakukan dimaksudkan untuk mempengaruhi calon konsumen agar membeli produknya dengan menawarkan keunggulan-keunggulan tententu pada produknya.

\section{Minat Beli Konsumen}

Pemasar harus memahami terlebih dahulu bagaimana konsumen berkeputusan untuk menarik dan menumbuhkan minat beli konsumen. Menurut Assael (2001:82) minat beli merupakan kecenderungan konsumen untuk membeli suatu merek atau mengambil tindakan yang berhubungan dengan pembelian. Yang diukur dengan tingkat kemungkinan konsumen melakukan pembelian.

Menurut Bearnman (2007:142) tumbuhnya minat beli konsumen itu disebabkan oleh unsur-unsur yang terdiri dari 3 tahapan: rangsangan, kesadaran, pencarian informasi

Menurut Ferdinand (2002:129), minat beli dapat diidentifikasi melalui indikator-indikator sebagai berikut:

a. Minat transaksional, yaitu kecenderungan seseorang untuk membeli produk

b. Minat referensial yaitu kecenderungan seseorang untuk mereferensikan produk kepada orang lain

c. Minat preferensial yaitu minat yang menggambarkan perilaku seseorang yang memiliki preferensi utama pada produk tersebut. Preferensi ini hanya dapat diganti jika terjadi sesuatu dengan produk preferensinya.

d. Minat exploratif, minat ini menggambarkan perilaku seseorang yang selalu mencari informasi mengenai produk yang diminatinya dan mencari informasi untuk mendukung sifatsifat positif dari produk tersebut.

Dalam menentukan minat beli konsumen mengenai produk atau jasa mana yang akan dikonsumsi, promosi seperti periklanan, penjualan langsung, promosi penjualan dan hubungan masyarakat sangat mempengaruhi minat dalam memberikan perhatian terhadap produk atau jasa, ketertarikan konsumen terhadap suatu produk atau jasa yang pada akhirnya konsumen akan memiliki keinginan untuk mencoba dan memutuskan untuk 
membeli. Hal utama yang dilakukan konsumen jika mereka cenderung menyukai suatu produk atau jasa tertentu, mereka akan selalu mencari informasi tentang produk atau jasa tertentu selanjutnya mereka akan membeli dan mereferensikannya kepada orang lain dan jika konsumen sudah memiliki pilihan yang lebih disukai terhadap produk atau jasa tertentu, mereka hanya akan mengganti jika terjadi sesuatu dengan produk preferensinya, ini terjadi pada proses minat beli konsumen dan sesuai karakteristik bauran promosi yang mempengaruhi minat beli konsumen.

\section{HASIL PENELITIAN / RESULTS}

1. Pengujian instrumen

Pengujian instrumen dengan SPSS versi 18, 2016 diperoleh hasil sebagai berikut:

a. Uji validitas

Untuk menguji valid dan tidak suatu instrumen. Item pertanyaan dikatakan valid apabila nilai nilai corrected item total correlation lebih besar dari nilai 0,224.

Tabel: 1

Hasil Uji Validitas Instrumen

\begin{tabular}{|c|c|c|c|c|c|c|}
\hline No. & Variabel & Indikator & $\begin{array}{c}r \\
\text { hitung }\end{array}$ & rtabel & $\begin{array}{c}\text { Nilai } \\
\text { sig }\end{array}$ & Keterangan \\
\hline 1 & \multirow{4}{*}{$\begin{array}{c}\text { Periklanan } \\
\text { (X } \\
1)\end{array}$} & $\mathrm{X} 1.1$ & $\begin{array}{c}0.64 \\
3 \\
\end{array}$ & 0.224 & 0,000 & Valid \\
\hline 2 & & $\mathrm{X} 1.2$ & $\begin{array}{c}0.73 \\
1\end{array}$ & 0.224 & 0,000 & Valid \\
\hline 3 & & $\mathrm{X} 1.3$ & $\begin{array}{c}0.71 \\
5\end{array}$ & 0.224 & 0,000 & Valid \\
\hline 4 & & $\mathrm{X} 1.4$ & $\begin{array}{c}0.66 \\
0 \\
\end{array}$ & 0.224 & 0,000 & Valid \\
\hline 5 & \multirow{4}{*}{$\begin{array}{c}\text { Penjualan } \\
\text { langsung (X2) }\end{array}$} & $\mathrm{X} 2.1$ & $\begin{array}{c}0.62 \\
9\end{array}$ & 0.224 & 0,000 & Valid \\
\hline 6 & & $\mathrm{X} 2.2$ & $\begin{array}{c}0.75 \\
4\end{array}$ & 0.224 & 0,000 & Valid \\
\hline 7 & & $\mathrm{X} 2.3$ & $\begin{array}{l}0.57 \\
8 \\
\end{array}$ & 0.224 & 0,000 & Valid \\
\hline 8 & & $\mathrm{X} 2.4$ & $\begin{array}{c}0.71 \\
0\end{array}$ & 0.224 & 0,000 & Valid \\
\hline 9 & \multirow{5}{*}{$\begin{array}{c}\text { Promosi } \\
\text { penjualan (X3) }\end{array}$} & $\mathrm{X} 3.1$ & $\begin{array}{c}0.44 \\
6 \\
\end{array}$ & 0.224 & 0,000 & Valid \\
\hline 10 & & $\mathrm{X} 3.2$ & $\begin{array}{c}0.74 \\
5\end{array}$ & 0.224 & 0,000 & Valid \\
\hline 11 & & $\mathrm{X} 3.3$ & $\begin{array}{c}0.71 \\
8\end{array}$ & 0.224 & 0,000 & Valid \\
\hline 12 & & $\mathrm{X} 3.4$ & $\begin{array}{c}0.81 \\
6 \\
\end{array}$ & 0.224 & 0,000 & Valid \\
\hline 13 & & $\mathrm{X} 3.5$ & $\begin{array}{c}0.68 \\
5\end{array}$ & 0.224 & 0,000 & Valid \\
\hline 14 & \multirow{4}{*}{$\begin{array}{c}\text { Hubungan } \\
\text { masyarakat (X4) }\end{array}$} & $\mathrm{X} 4.1$ & $\begin{array}{c}0.71 \\
7\end{array}$ & 0.224 & 0,000 & Valid \\
\hline 15 & & $\mathrm{X} 4.2$ & $\begin{array}{c}0.82 \\
1\end{array}$ & 0.224 & 0,000 & Valid \\
\hline 16 & & $\mathrm{X} 4.3$ & $\begin{array}{c}0.79 \\
8\end{array}$ & 0.224 & 0,000 & Valid \\
\hline 17 & & $\mathrm{X} 4.4$ & $\begin{array}{c}0.71 \\
5\end{array}$ & 0.224 & 0,000 & Valid \\
\hline 18 & \multirow{4}{*}{$\begin{array}{l}\text { Minat memilih } \\
\quad(\mathrm{Y})\end{array}$} & $\mathrm{Y} 1$ & 0.775 & 0.224 & 0,000 & Valid \\
\hline 19 & & $\mathrm{Y} 2$ & 0.818 & 0.224 & 0,000 & Valid \\
\hline 20 & & $\mathrm{Y} 3$ & 0.794 & 0.224 & 0,000 & Valid \\
\hline 21 & & $\mathrm{Y} 4$ & 0.758 & 0.224 & 0,000 & Valid \\
\hline
\end{tabular}

Sumber: Hasil pengolahan data primer, SPSS 18, 2016

Berdasarkan hasil uji validitas dari item pertanyaan variabel penelitian diperoleh nilai $r$ hitung terendah - tertinggi $(0,446-0,821)>\mathrm{r}$ tabel $(0,224)$ dengan nilai sig. $(0,000)$, maka dapat disimpulkan bahwa instrumen dalam penelitian ini adalah valid.

b. Uji reliabilitas.

Uji reliabilitas adalah indeks sejauh mana alat ukur dapat dipercaya atau dapat diandalkan atau menunjukkan konsistensi suatu alat pengukur di dalam mengukur gejala yang sama.

Tabel 2. Hasil uji reliabilitas instrumen

\begin{tabular}{|l|c|c|}
\hline \multicolumn{1}{|c|}{ Variabel } & Cronbach's Alpha & $\begin{array}{c}\text { N of } \\
\text { items }\end{array}$ \\
\hline Periklanan (X1) & 0,768 & 5 \\
\hline Penjualan langsung(X2) & 0,756 & 5 \\
\hline Promosi penjualan(X3) & 0,771 & 6 \\
\hline $\begin{array}{l}\text { Hubungan } \\
\text { masyarakat(X4) }\end{array}$ & 0,798 & 5 \\
\hline $\begin{array}{l}\text { Minat memilih prodi } \\
\text { Manajemen(Y) }\end{array}$ & 0,810 & 5 \\
\hline
\end{tabular}

Sumber: Hasil pengolahan data primer, SPSS versi 18, 2016

Berdasarkan hasil uji reliabilitas dari item pertanyaan variabel penelitian diperoleh nilai Cronbach's Alpha $>0,60$ sehingga dapat disimpulkan bahwa instrumen dalam penelitian ini realiabel dan dapat digunakan sebagai alat ukur penelitian yang baik.

\section{Deskripsi data hasil penelitian}

Dari semua kuesioner yang dibagikan yaitu sebanyak 110 kuesioner yang dapat diolah dan ditabulasi untuk tujuan analisis data sebanyak 77 kuesioner. Data ditabulasi adalah semua tanggapan atau jawaban responden atas setiap pertanyaan yang ada dalam kuesioner. Pertanyaan-pertanyaan berkaitan dengan variabel-variabel periklanan sebanyak 4 indikator dengan 4 
pernyataan, variabel penjualan langsung sebanyak 4 indikator dengan 4 pernyataan, variabel promosi penjualan sebanyak 5 indikator dengan 5 pernyataan, hubungan masyarakat sebanyak 4 indikator dengan 4 pernyataan dan minat mahasiswa memilih prodi Manajemen sebanyak 4 indikator dengan 4 penyataan.Skor semua variabel ini diukur dengan skala likert (Supriyanto 2009:99) menjadi 4 tingkatan yaitu: sangat setuju skor $=4$, setuju skor $=3$, ragu-ragu skor $=2$, dan tidak setuju skor $=1$.

Berdasarkan data variabel periklanan, penjualan langsung, promosi penjualan, hubungan masyarakat dan minat mahasiswa memilih prodi Manajemen penulis mengklasifikasi ke dalam 4 kategori yakni sangat efektif (4), efektif(3), cukup efektif(2), kurang efektif(1).

Data hasil tabulasi yang diolah secara deskriptif statistik seperti tabel berikut:

a. Bauran promosi UMSurabaya

Tabel 3.

Distribusi prosentase variabel bauran promosi

\begin{tabular}{|c|c|c|c|c|c|c|c|c|c|c|c|}
\hline \multirow{3}{*}{ No } & \multirow{3}{*}{ 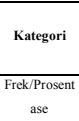 } & \multicolumn{8}{|c|}{ Bauran Promosi } & \multirow{3}{*}{$\begin{array}{c}\text { Jumla } \\
\text { h } \\
\text { F }\end{array}$} & \multirow{3}{*}{$\begin{array}{c}\begin{array}{l}\text { Prose } \\
\text { ne }\end{array} \\
\%\end{array}$} \\
\hline & & \multicolumn{2}{|c|}{ Advertising } & \multicolumn{2}{|c|}{$\begin{array}{l}\text { Personal } \\
\text { Selling }\end{array}$} & \multicolumn{2}{|c|}{$\begin{array}{c}\text { Sales } \\
\text { Promotion }\end{array}$} & \multicolumn{2}{|c|}{ Publicity } & & \\
\hline & & $\mathrm{F}$ & $\%$ & F & $\%$ & $\mathrm{~F}$ & $\%$ & $F$ & $\%$ & & \\
\hline 1. & $\begin{array}{c}\text { Sangat } \\
\text { efrckifif(4) }\end{array}$ & $\begin{array}{l}1 \\
3\end{array}$ & $\begin{array}{c}16, \\
9\end{array}$ & $\begin{array}{l}1 \\
2\end{array}$ & $\begin{array}{c}15, \\
6\end{array}$ & $\begin{array}{l}1 \\
9\end{array}$ & $\begin{array}{l}24, \\
7\end{array}$ & $\begin{array}{l}1 \\
7\end{array}$ & $\begin{array}{c}22, \\
2\end{array}$ & 61 & 19,8 \\
\hline 2. & Effkktif(3) & $\begin{array}{l}5 \\
5\end{array}$ & $\begin{array}{c}71, \\
4\end{array}$ & $\begin{array}{l}4 \\
5\end{array}$ & $\begin{array}{r}58, \\
4\end{array}$ & $\begin{array}{l}4 \\
9\end{array}$ & $\begin{array}{c}63, \\
6 \\
6\end{array}$ & $\begin{array}{l}5 \\
3\end{array}$ & $\begin{array}{c}68, \\
8\end{array}$ & 202 & 65,6 \\
\hline 3. & $\begin{array}{l}\text { Cuklup } \\
\text { effektif(2) }\end{array}$ & 7 & 9,1 & $\begin{array}{l}1 \\
8\end{array}$ & $\begin{array}{c}23, \\
4\end{array}$ & 7 & 9,1 & 6 & 7,7 & 38 & 12,4 \\
\hline 4. & $\begin{array}{c}\text { Kurang } \\
\text { efcktif(1) }\end{array}$ & 2 & 2,6 & 2 & 2,6 & 2 & 2,6 & 1 & 1,3 & 7 & 2,2 \\
\hline & Jumlah & 7 & $\begin{array}{c}10 \\
0\end{array}$ & 7 & $\begin{array}{l}10 \\
0\end{array}$ & $\begin{array}{l}7 \\
7\end{array}$ & 10 & 7 & 10 & 308 & 100 \\
\hline
\end{tabular}

Sumber: Hasil pengolahan data primer, 2017

Berdasarkan data di atas dapat disimpulkan bahwa mayoritas responden yang memilih bauran promosi (periklanan, penjualan langsung, promosi penjualan dan hubungan masyarakat) masing-masing sebesar: $19,8 \%$ masuk kategori sangat efektif, $65,6 \%$ masuk kategori efektif, $12,4 \%$ masuk kategori cukup efektif dan 2,2\% masuk kategori kurang efektif. Hal ini menunjukan bahwa bauran promosi yang dilakukan UMSurabaya sudah efektif sesuai dengan kebutuhan konsumen.
Berdasarkan analisisis deskriptif dan paparan data yang diperoleh di lapangan mengenai:

1) Periklanan

Hasil deskripsi data variabel periklanan diperoleh nilai $16,9 \%$ jawaban responden masuk kategori sangat efektif dan $71,4 \%$ jawaban responden masuk kategori efektif, hal ini menunjukkan bahwa periklanan yang dilakukan oleh UMSuarabaya sudahefektif untuk mempengaruhi minat memilih prodi Manajemen FEB UMSurabaya. UMSurabaya menggunakan media iklan untuk menunjang kegiatan promosi yaitu: a) melalui media cetak seperti koran dan majalah b) melalui media penyiaran seperti $\mathrm{TV}$, radio c) melalui media jaringan seperti telepon, HP d) melalui media elektronik seperti : rekaman vidio, $\mathrm{CD}$, rekaman suara e) melalui website f) media pameran seperti billboard, papan penunjuk jalan, spanduk dan poster, dll (Wawancara denganTim LIPMB Mussayidatul Ummah, S.Pd, 27 Mei 2017).

2) Penjualan langsung

Hasil deskripsi data variabel penjualan langsung diperoleh nilai $15,6 \%$ jawaban responden masuk kategori sangat efektif dan $58,4 \%$ jawaban responden masuk kategori efektif, hal ini menunjukkan bahwa penjualan langsung yang dilakukan oleh UMSuarabaya sudah efektif untuk mempengaruhi minat memilih prodi Manajemen FEB UMSurabaya. LIPMB UMSurabaya melalui 2 cara berinteraki yaitu: penjualan langsung yang interaktif dan interaktif dari perusahaan yang interaktif. a) Penjualan langsung yang interaktif dilakukan dengan cara pramuniaga LIPMB yang berinteraksi dengan konsumen. Setiap konsumen yang datang dan mendaftar pramuniaga LIPMB UMSurabaya akan menyambut dengan ramah dan menawarkan 
setiap prodi yang dimiliki. b) Interaksi dari perusahaan yang interaktif dilakukan melalui kunjungan langsung ke SLTA di Jawa Timur maupun luar jawa melalui duta kampus dari masingmasing prodi, mengikuti pameran pendidikan, memasang iklan di website UMSurabaya dan website masing-masing fakultas, dll. (Hasil wawancara denganTim LIPMB Mussayidatul Ummah, S.Pd, 27 Mei 2017).

3) Promosi penjualan

Hasil deskripsi data variabel penjualan langsung diperoleh nilai $24,7 \%$ jawaban responden masuk kategori sangat efektif dan $63,6 \%$ jawaban responden masuk kategori efektif, hal ini menunjukkan bahwa promosi penjualanyang dilakukan oleh UMSuarabaya sudah efektif untuk mempengaruhi minat memilih prodi Manajemen FEB UMSurabaya. Untuk mendorong minat memilih prodi UMSurabaya menawarkan program unggulan 10 jenis beasiswa yaitu :beasiswa bidikmisi, beasiswa prestasi, beasiswa alumni SLTA Muhammadiyah, beasiswa atlit, beasiswa kader, beasiswa difabel berdaya, beasiswa warga sekitar, beasiswa jalur undangan dan alumni SMK Kesehatan, dan beasiswa insan muda kreatif, putra/i perawat dan bidan. (Hasil wawancara denganTim LIPMB Mussayidatul Ummah, S.Pd, 27 Mei 2017).

4) Hubungan masyarakat

Hasil deskripsi data variabel hubungan masyarakat diperoleh nilai $22,2 \%$ jawaban responden masuk kategori sangat efektif dan $68,8 \%$ jawaban responden masuk kategori efektif, hal ini menunjukkan bahwa hubungan masyarakat yang dilakukan oleh UMSuarabaya sudah efektif untuk mempengaruhi minat memilih prodi Manajemen FEB UMSurabaya.
Hubungan masyarakat memiliki 3 indikator yaitu: berita baik yang tersebar mengenai perusahaan, identitas perusahaan yang unik berbeda dengan yang lainnya, dan kegiatan pelayanan kepada masyarakat. Hubungan masyarakat dilakukan melalui berbagai program untuk mempromosikan atau melindungi citra UMSurabaya a) melalui kegiatan publikasi seperti melakukan kegiatan pengabdian masyarakat, bakti sosial, nonton bareng bersama pak Rektor dengan bonek persebaya pada ajang kompetisi LIGA 2) melakukan publikasi ilmiah pada jurnal-jurnal nasional, jurnal terakreditasi maupun terindek scopus maupun forum-forum ilmiah, pengurusan HAKI bagi karya dosen dan mahasiswa, dll 3) kerjasama regional antar perguruan tinggi di dalam maupun di luar negeri seperti antara lain kerjasama di bidang kedokteran dan kesehatan antara UMSurabaya berserta Pimpinan Pusat Muhammadiyah dengan Pemerintah Jepang.(Hasil pengamatan dan wawancara denganLIPMB Mussayidatul Ummah, S.Pd, 27 Mei 2017).

b. Minat memilih prodi Manajemen FEB UMSurabaya

Tabel 4

Distribusi prosentase variabel minat memilih

\begin{tabular}{|c|c|c|c|c|c|c|c|c|c|c|c|}
\hline \multirow[b]{2}{*}{ No } & \multirow[b]{2}{*}{ Kategori } & \multicolumn{8}{|c|}{ Minat Memilih Prodi Manajemen } & \multirow[b]{2}{*}{$\begin{array}{c}\text { Jumla } \\
\mathbf{h}\end{array}$} & \multirow[b]{2}{*}{$\begin{array}{l}\text { Prosentas } \\
\text { e }\end{array}$} \\
\hline & & & & & & & & & & & \\
\hline & $\begin{array}{l}\text { Frek/Prose } \\
n\end{array}$ & $\mathrm{~F}$ & $\%$ & $\mathrm{~F}$ & $\%$ & $\mathrm{~F}$ & $\%$ & $\mathrm{~F}$ & $\%$ & $\mathrm{~F}$ & $\%$ \\
\hline 1. & $\begin{array}{l}\text { Sangat } \\
\text { efeckifif) }\end{array}$ & 38 & & $\begin{array}{l}2 \\
6\end{array}$ & & 20 & & $\begin{array}{l}2 \\
8\end{array}$ & & 112 & $36,4 \%$ \\
\hline 2. & Efektif(3) & 39 & & $\begin{array}{l}4 \\
3\end{array}$ & & 52 & & 4 & & 178 & $57,8 \%$ \\
\hline 3. & $\begin{array}{c}\text { Cukup } \\
\text { efcktif(2) }\end{array}$ & 0 & & 8 & & 5 & & 5 & & 18 & $5,8 \%$ \\
\hline 4. & $\begin{array}{l}\text { Kurang } \\
\text { efektif(1) }\end{array}$ & 0 & & 0 & & 0 & & 0 & & 0 & $0 \%$ \\
\hline & Jumlah & 77 & & $\begin{array}{l}7 \\
7\end{array}$ & & 77 & & $\begin{array}{l}7 \\
7\end{array}$ & & 308 & $100 \%$ \\
\hline
\end{tabular}

Sumber: Hasil pengolahan data primer, 2017

Berdasarkan data di atas dapat disimpulkan bahwa mayoritas responden yang memilih jawaban minat(transaksional,referensial,prefer ensial dan exploratife)memilih prodi 
Balance Vol. XV No. 1 | Januari 2018

Manajemenberturut-turut sebesar:36,4\% masuk kategori sangat efektif, 57,8\% masuk kategori efektif, 5,8\% masuk kategori cukup efektif dan $0 \%$ kurang efektif. Hal ini menunjukkan bahwa minat memilih prodi Manajemen didorong oleh minat: transaksional, referensial, preferensial dan exploratife.

3. Analisis Data

1. Uji Asumsi Klasik Pengujian Hipotesis

a) Uji Normalitas

Hasil uji normalitas dapat di lihat dari grafik yang berikut:

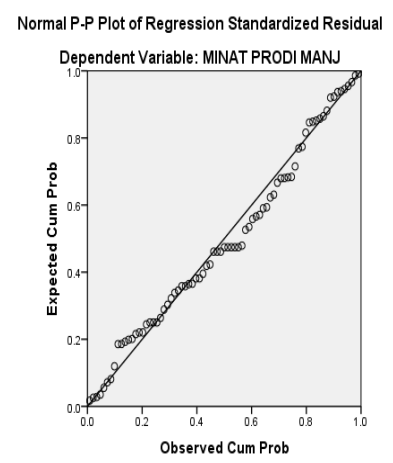

Gambar. 1

Dari grafik tersebut, terlihat titik-titik menyebar di sekitar garis diagonal serta penyebarannya mengikuti arah garis diagonal, maka model regresi layak dipakai untuk mengetahui minat mahasiswa memilih Prodi Manajemen berdasarkan masukan variabel independennya yaitu periklanan, penjualan langsung, promosi penjualan dan hubungan masyarakat.

Pengujian normalitas dilakukan dengan metode kolmogorov-smirnov test seperti pada tabel berikut :
Hasil uji dengan metode kolmogorov-smirnov test

One-Sample Kolmogorov-Smirnov Test

\begin{tabular}{|c|c|c|}
\hline & & Unstandardized Residual \\
\hline \multicolumn{2}{|l|}{$\mathrm{N}$} & 77 \\
\hline \multirow{3}{*}{$\begin{array}{c}\text { Normal } \\
\text { Parameters }{ }^{\mathrm{a}, \mathrm{b}}\end{array}$} & Mean & $0 \mathrm{E}-7$ \\
\hline & Std. & .36094191 \\
\hline & Deviation & \\
\hline \multirow{3}{*}{$\begin{array}{c}\text { Most Extreme } \\
\text { Differences }\end{array}$} & Absolute & .093 \\
\hline & Positive & .093 \\
\hline & Negative & -.075 \\
\hline \multicolumn{2}{|c|}{ Kolmogorov-Smirnov Z } & .814 \\
\hline \multicolumn{2}{|c|}{ Asymp. Sig. (2-tailed) } & .521 \\
\hline
\end{tabular}

Sumber: Hasil pengolahan data primer, SPSS versi 18 , 2016

Pada hasil uji normalitas menggunakan metode kolmogorov-smirnov test yang tersebut di atas dapat dilihat pada kolom signifikansi (Asymp. Sig.(2-tailed) nilai sebesar 0,521 adalah lebih besar dari 0,05 maka H0 diterima dan H1 ditolak, hal ini berarti populasi berdistribusi normal.

2. Analisis Regresi Linier Berganda

Analisis regresi linier berganda digunakan untuk mengetahui pengaruh antara variabel bebas (X) terhadap variabel terikat (Y). Melalui Program SPSS versi 18, 2016 menghasilkan out put seperti tabel berikut:

Tabel: 6

Uji Regresi Linier (Coefficient)

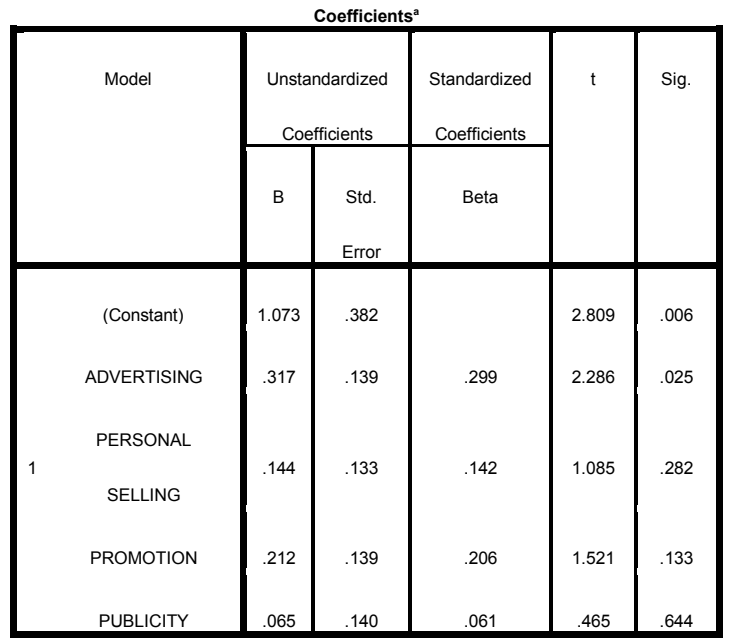

Tabel 5 
Sumber: Hasil pengolahan data primer, SPSS versi 18, 2016

Berdasarkan hasil perhitungan tersebut di atas, diperoleh persamaan regresi linier berganda sebagai berikut: $\mathrm{Y}=1.073+0.317(\mathrm{X} 1)+0.144(\mathrm{X} 2)+$ $0.212(\mathrm{X} 3)+0.065(\mathrm{X} 4)$

Dari persamaan regresi tersebut menunjukkan bahwa konstanta $(\mathrm{b} 0)=$ 1.073, menunjukkan bahwa besarnya pengaruh semua variabel bebas terhadap vaeriabel terikat, apabila variabel bebasnya $=0$ atau konstan yang artinya tanpa adanya empat variabel bebas di atas, maka akan menaikkan variabel $\mathrm{Y}$ sebesar 1.073. Adapun koefisien regresi untuk X1 $=0.317$ menunjukkan bahwa apabila variabel ini mengalami kenaikan sebesar satu satuan, maka variabel Y akan mengalami kenaikan sebesar 0.317 dengan asumsi variabel yang lain adalah konstan atau $=0$, koefisien regresi untuk $\mathrm{X} 2=0.144$ menunjukkan bahwa apabila variabel ini mengalami kenaikan sebesar satu satuan, maka variabel $\mathrm{Y}$ akan mengalami kenaikan sebesar 0.144 dengan asumsi variabel yang lain adalah konstan atau $=0$, koefisien regresi untuk X3 $=0.202$ menunjukkan bahwa apabila variabel ini mengalami kenaikan sebesar satu satuan, maka variabel $\mathrm{Y}$ akan mengalami kenaikan sebesar 0.202 dengan asumsi variabel yang lain adalah konstan atau $=0$, begitu juga koefisien regresi untuk X4 $=0.065$ menunjukkan bahwa apabila variabel ini mengalami kenaikan sebesar satu satuan, maka variabel $\mathrm{Y}$ akan mengalami kenaikan sebesar 0.065 dengan asumsi variabel yang lain adalah konstan atau $=0$.

Dari persamaan regresi di atas dapat diketahui bahwa semua variabel bebas mempunyai nilai koefisien yang positif, hal ini mengidentifikasikan bahwa periklanan, penjualan langsung, promosi penjualan dan hubungan masyarakat mempunyai hubungan positif terhadap minat memilih prodi Manajemen. Artinya minat mahasiswa memilih prodi Manajemen akan meningkat jika periklanan, penjualan langsung, promosi penjualan dan hubungan masyarakat mengalami peningkatan.

3. Pengujian Hipotesis

a) Pengujian

Koefisien

Determinan $\left(\mathrm{R}^{2}\right)$

Analisis

koefisien

determinan $\left(\mathrm{R}^{2}\right)$ digunakan untuk mengetahui seberapa

besar prosentase sumbangan pengaruh variabel independen secara serentak terhadap variabel dependen sedangkan sisanya dipengaruhi oleh faktor lain. Berikut ini adalah hasil uji koefisien determinan $\left(\mathrm{R}^{2}\right)$ dengan bantuan SPSS versi 18 , 2016.

Tabel : 7

Hasil Uji Regresi Linier (Model Summaryb)

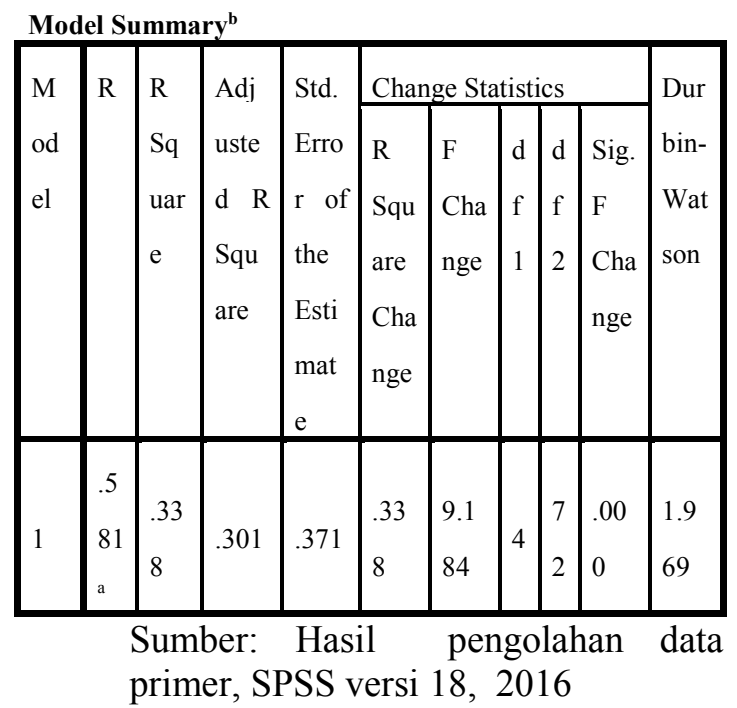


Dari tabel tersebut di dapatkan $\left(\mathrm{R}^{2}\right)$ sebesar 33,8. Hal ini berarti $33,8 \%$ minat memilih prodi Manajemen FEB UMSurabaya dipengaruhi oleh variabel bebas $(\mathrm{X})$ yaitu variabel periklanan (X1), penjualan langsung (X2), promosi penjualan (X3) dan hubungan masyarakat (X4) terhadap variabel dependen (Y) yaitu variabel minat memilih prodi Manajemen adalah sebesar 33,8\%. Sedangkan sisanya $66,2 \%$ dipengaruhi oleh faktor-faktor variabel lain yang tidak disebutkan dalam penelitian ini.

b). Pengujian Simultan (F-test)

Uji hipotesis dengan $\mathrm{F}$ test ini digunakan untuk menguji pengaruh variabel periklanan, penjualan langsung, promosi penjualan dan hubungan masyarakat secara simultan terhadap variabel minat memilih prodi Manajemen. Dari hasil perhitungan SPSS versi 18 , 2016 di diperoleh data sebagai berikut:

Tabel: 8 Data Hasil Uji F

\begin{tabular}{|c|c|c|c|c|c|}
\hline Model & $\begin{array}{l}\text { Sum of } \\
\text { Squares }\end{array}$ & $\mathrm{df}$ & $\begin{array}{l}\text { Mean } \\
\text { Square }\end{array}$ & $\mathrm{F}$ & Sig. \\
\hline Regression & 5.052 & 4 & 1.263 & 9.184 & $.000^{\mathrm{b}}$ \\
\hline 1 Residual & 9.901 & 72 & .138 & & \\
\hline Total & 14.953 & 76 & & & \\
\hline
\end{tabular}

Sumber: Hasil pengolahan data primer, SPSS versi 18, 2016

Berdasarkan hasil Uji $F$ yang dilakukan dalam penelitian ini diperoleh hasil Uji $F$ dalam tabel anova didapatkan nilai F-hitung
(9.184), sedangkan nilai $\mathrm{F}$ tabel sebesar 2.47 dengan tingkat signifikansi $\quad 0,05$, maka dapat ditarik kesimpulan bahwa F-hitung $>$ F-tabel, yang berarti $\mathrm{H} 0$ ditolak artinya variabel periklanan (X1), penjualan langsung (X2), promosi penjualan (X3), dan hubungan masyarakat (X4) berpengaruh positif yang signifikan terhadap minat mahasiswa memilih Prodi Manajemen FEB UMSurabaya (Y).

\section{c). Pengujian Parsial (t-test)}

Uji parsial digunakan untuk menguji secara individual apakah masingmasing variabel independen (periklanan, penjualan langsung, promosi penjualan dan hubungan masyarakat) berpengaruh secara parsial terhadap variabel dependen minat memilih prodi Manajemen.Hasil output pengujian data secara parsial menggunakan SPSS versi 18 , 2016 seperti tabel berikut:

Tabel :9 Data Hasil UJI Parsial (t-test)

\begin{tabular}{|c|c|c|c|c|c|}
\hline Coefficients $^{\mathrm{a}}$ & & & & & \\
\hline \multirow[t]{2}{*}{ Model } & \multicolumn{2}{|c|}{$\begin{array}{l}\text { Unstandardiz } \\
\text { ed } \\
\text { Coefficients }\end{array}$} & $\begin{array}{l}\text { Standardiz } \\
\text { ed } \\
\text { Coefficient }\end{array}$ & \multirow[t]{2}{*}{$\mathrm{t}$} & \multirow[t]{2}{*}{ Sig } \\
\hline & B & $\begin{array}{l}\text { Std. } \\
\text { Erro } \\
\mathrm{r}\end{array}$ & Beta & & \\
\hline 1 (Constant) & 1.073 & .382 & & \begin{tabular}{|l}
2.80 \\
9
\end{tabular} & $\begin{array}{l}.00 \\
6\end{array}$ \\
\hline
\end{tabular}




\begin{tabular}{l|l|l|l|l|l|} 
ADVERTISI & .317 & .139 & .299 & 2.28 & .02 \\
NG & & & & 6 & 5 \\
PERSONAL & .144 & .133 & .142 & 1.08 & .28 \\
SELLING & & & & 5 & 2 \\
PROMOTION & .212 & .139 & .206 & 1.52 & .13 \\
& & & & 1 & 3 \\
PUBLICITY & .065 & .140 & .061 & .465 & .64 \\
\hline
\end{tabular}

Sumber: Hasil pengolahan data primer, SPSS versi 18, 2016

Berdasarkan hasil Uji t
yang dilakukan dalam
penelitian ini diperoleh hasil t-
hitung variabel periklanan
$(2.286)$

dibandingkan dengan $\mathrm{t}$ - tabel (1.586), dapat disimpulkan bahwa terdapat pengaruh positif yang signifikan antara periklanan terhadap minat memilih Prodi Manajemen FEB UMSurabaya. Hasil thitung variabel penjualan langsung (1.085), promosi penjualan $(0,212)$, hubungan masyarakat $(0,065)$ lebih kecil dari t-tabel (1.586), yang berarti penjualan langsung, promosi penjualan dan hubungan masyarakat tidak mempunyai pengaruh yang signifikan terhadap minat memilih Prodi Manajemen FEB UMSurabaya.

\section{PEMBAHASAN}

Berdasarkan data hasil penelitian

maka pembahasan mengenai hasil

penelitian dapat dijelaskan sebagai

berikut:

1. Bauran promosi UMSurabaya

Dilihat dari sisi periklanan, data hasil penelitian menunjukkan bahwa periklanan berpengaruh paling dominan terhadap minat memilih prodi Manajemen. Hal ini berarti bahwa periklanan yang dilakukan UMSurabaya sangat agresif, kreatif, inovatif dan efektif. Hal ini dapat dibuktikan dengan adanya berbagai macam kerjasama seperti 1) kerjasama siaran dengan pihak Metro TV, Radio SS, M Radio 2) kerjasama berita koran serperti Surya, Birawa, Radar dan Jawa Pos 3) kerjasama dengan majalah ; Suara Muhammadiyah, Matan, Walida dan Lazismu, dll 4) kerjasama website ; PWMU, universitas dan fakultas 5) kerjasama dengan media cetak seperti

kalender, brosur, baliho, liflet, dll 6) pemanfaatan media sosial seperti fase book, istagram, WA( Nara sumber Tim LIPMB UMSurabaya Saudari Mussayidatul Ummah, S.Pd). Periklanan merupakan media komunikasi yang efektif untuk menyampaikan pesan mengenai produk yang ditawarkan perusahaan untuk merangsang minat konsumen untuk memebli. Kondisi ini sesuai dengan teori yang dijelaskan Hermawan (2012:39) yang menyatakan bahwa iklan merupakan media utama untuk menunjang promosi dengan tujuan untuk menarik konsumen agar mau melakukan pembelian. William G.Nickels mengemukakan bahwa periklanan adalah komunikasi nonpribadi dengan sejumlah biaya, melalui berbagai media yang dilakukan oleh perusahaan, lembaga non-laba, serta individu(Haryono,2012). Kondisi ini juga didukung oleh hasil penelitian Anggraheni Oktavia P (2016) yang 
menyatakan bahwa variabel periklanan (X1) mempunyai pengaruh yang signifikan terhadap minat beli konsumen di MCDonald's cabang Rungkut Surabaya.Berdasarkan kajian tersebut, jika prodi Manajemen ingin meningkatkan jumlah mahasiswanya maka periklanan merupakan strategi yang penting untuk diterapkan dengan lebih menarik dan lebih atraktif lagi.

Dari sisi penjualan langsung, data hasil penelitian menunjukkan bahwa penjualan langsung belum terlalu efektif, dari hasil analisis t test yang menunjukkan pengaruh positif tidak signifikan. Penjualan langsung dilakukan UMSurabaya melalui : kunjungan ke SLTA di wilayah Jawa Timur dan juga luar jawa melaui duta kampus dari masing-masing prodi, stand pameran pendidikan baik nasional maupun internasional, program PPL dan KKN di Tailan Selatan oleh FKIP dan FAI pada bulan Agustus 2017, stand pendaftaran di kampus, website UMSurabaya, WA dan HP Tim LIPMB, namun karena siswa SLTA sedang proses penyelesaikan pendidikan akhir untuk mendapatkan ijazah, sehingga posisi pada pendaftaran gelombang I dan II kebanyakan pendaftar adalah alumni SLTA yang lulus tahun sebelumnya dan belum kuliah, dan pada umumnya UMSurabaya ini masih merupakan pilihan kedua bahkan ketiga setelah Perguruan Tinggi Negeri.(Hasil wawancara dengan Tim LIPMB UMSurabaya Mussayidatul Ummah, S.Pd). Hal ini sesuai dengan penelitian yang dilakukan oleh Tristantin dan Suwandi (2013)yang menyatakan bahwa pemasaran langsung kurang efektif.
Dari sisi promosi penjualanuntuk mendorong minat memilih prodi UMSurabaya menawarkan program unggulan 10 jenis beasiswa yaitu : beasiswa bidikmisi, beasiswa prestasi, beasiswa alumni SLTA Muhammadiyah, beasiswa atlit, beasiswa kader, beasiswa difabel berdaya, beasiswa warga sekitar, beasiswa jalur undangan dan alumni SMK Kesehatan, dan beasiswa insan muda kreatif, putra/i perawat dan bidan. (Hasil wawancara denganTim LIPMB Mussayidatul Ummah, S.Pd, 27 Mei 2017). Kondisi sesuai dengan teori yang dijelaskan Rambat Lupiyoadi (2013: 187) yang menyatakan bahwa " Promosi konsumen (comsumer's promotion), merupakan kegiatan promosi yang ditujukan kepada konsumen akhir, yaitu dengan memberikan hadiah promosi dan diskon khusus". Namun demikian promosi penjualan yang dilakukan oleh LIPMB UMSurabaya tidak cukup efektif untuk mendorong minat memilih prodi Manajemen. Promosi penjualan ini tidak terlalu memberikan kontribusi terhadap minat memilih prodi Manajemen karena tidak semua calon mahasiswa memiliki persyaratan untuk mendapatkan potongan biaya kuliah. Kondidi ini didukung oleh penelitian Tri Yulianti (2013) yang menyatakan bahwa variabel personal selling dan promosi penjualan (X) tidak memiliki pengaruh terhadap keputusan pembelian sepeda motor Yamaha (Y).

Dari sisi hubungan masyarakat, datahasil penelitian menunjukkan bahwa hubungan masyarakat belum terlalu efektif, dari hasil 
analisis t-test variabel hubungan masyarakat menunjukkan pengaruh positif tidak signifikan terhadap minat memilih prodi Manajemen. Kondisi ini sesuai dengan hasil penelitian Adhina Nugraheni(2013) yang menyatakan bahwa tidak ada pengauruh positif dan signifikan hubungan masyarakat terhadap keputusan pembelian. Hubungan masyarakat memiliki 3 indikator yaitu: berita baik yang tersebar mengenai perusahaan, identitas perusahaan yang unik berbeda dengan yang lainnya, dan kegiatan pelayanan kepada masyarakat. Hubungan masyarakat dilakukan melalui berbagai program untuk mempromosikan atau melindungi citra UMSurabaya a) melalui kegiatan publikasi seperti melakukan kegiatan pengabdian masyarakat, bakti sosial, nonton bareng dengan bonex persebaya

2) melakukan publikasi ilmiah pada jurnal-jurnal nasional, jurnal terakreditasi maupun terindek scopus maupun forum-forum ilmiah, pengurusan HAKI bagi karya dosen dan mahasiswa, dll 3) kerjasama regional antar perguruan tinggi di dalam maupun di luar negeri seperti antara lain kerjasama di bidang kedokteran dan kesehatan antara UMSurabaya berserta Pimpinan Pusat Muhammadiyah dengan Pemerintah Jepang.(Hasil pengamatan dan wawancara denganTim LIPMB Mussayidatul Ummah, S.Pd, 27 Mei 2017).

2. Minat mahasiswa memilih Prodi Manajemen

Minat beli konsumen (Y) ialah perilaku yang muncul sebagai respon terhadap obyek, indikator minat beli meliputi minat transaksional, minat referensial, minat preferensial dan minat exploratif yakni mencari informasi untuk mendukung sifat-sifat positif dari/atau mengenai Prodi Manajemen FEB UMSurabaya.

Berdasarkan hasil data yang diolah dapat disimpulkan bahwa mayoritas mahasiswa yang memilih Prodi Manajemen dipengaruhi oleh minat transaksional, minat referensial, minat preferensial, dan minat eksploratif dalam kategori efektif. Hal ini dilihat dari data sejumlah 77 orang responden sebagai obyek penelitian terdapat 28 responden atau $36,4 \%$ dari jumlah responden memilih jawaban sangat setuju, sebanyak 44 responden atau $57,8 \%$ memilihsetuju, dan 5 responden atau 5,8\% memilih cukup setuju.Hal ini berarti mayoritas mahasiswa memilih prodi manajemen ini dilandari oleh minat transaksional, referensial, preferensian dan exploratif. Kondisi ini didukung dari hasil wawancara dengan Tim LIPMB Mussayidatul Ummah, S.Pd, 27 Mei 2017 yang menyatakan bahwa pada umumnya minat masuk UMSurabaya dilandari oleh minat referensial yang didominasi oleh para keluarga mahasiswa, tetangga keluarga mahasiswa, teman dan alumni melalui komunikasi langsung yang tergolong pada bauran promosi penjualan langsung. Oleh karena itu kepuasan pelanggan bagi stakeholders menjadi penting untuk diperhatikan.

\section{KESIMPULAN DAN SARAN}

Berdasarkan hasil penelitian dan pembahasan yang telah dilakukan, 
maka dapat ditarik kesimpulan sebagai berikut:

1. Karakteristik mahasiswa prodi Manajemen UMSurabaya diketahui 58\% berjenis kelamin perempuan dan sisanya adalah mahasiswa berjenis kelamin lakilaki yang di dominasi oleh usia antara 20 - 25 tahun dengan tingkat pendapatan orang tua/wali antara Rp.1.000.000,- - Rp. 4.000.000,- per bulan dan 73\% mahasiswa berasal dari kota Surabaya .

2. Bauran promosi yang terdiri dari periklanan, penjualan langsung, promosi penjualan dan hubungan masyarakat yang diterapkan di LIPMB UMSurabaya telah dilaksakan dengan efektif sesuai dengan informasi yang dibutuhkan para calon mahasiswa yang semula tidak berminat menjadi berminat untuk memilih Prodi Manajemen FEB UMSurabaya.

3. Minat mahasiswa memilih Prodi Manajemen FEB UMsurabaya dipegaruhi oleh minat transaksional, minat referensial, minat preferensial dan minat exploratif. Minat referensial lebih efektif karena pada umumnya bersumber dari hubungan keluarga, pertetanggaan, dan pertemanan.

4. Variabel periklanan, penjualan langsung, promosi penjualan dan hubungan masyarakat secara simultan berpengaruh signifikan terhadap minat memilih Prodi Manajemen FEB UMSurabaya.

5. Variabel priklanan berpengaruh yang paling dominan terhadap minat mahasiswa memilih Prodi Manajemen
Peneliti memberikan saran untuk peneliti selanjutnya, yaitu:

1. Menambah jumlah sampel yang diteliti, dengan demikian tingkat generalisasi dari analisis akan lebih akurat.

2. Menambah variabel yang belum diteliti yang memiliki kemungkinan untuk berpengaruh terhadap hubungan antara promosional mix terhadap minat beli konsumen

\section{DAFTAR PUSTAKA}

Alma, Buchari. (2005). Manajemen Pemasaran dan Pemasaran Jasa. Bandung: Alfabeta

\section{Bandung: Alfabeta}

Anwar, S. (2009). Metode Penelitian Kuantitatif dan Kualitatif. Yogyakarta: Penerbit Andi

Assauri, Sofjan. (2010). Manajen Pemasaran Dasar. Penerbit Rajawali Pers,

Assael, Henry (2001) , Consumer Beharviour, 6 th Edition. New York: Thomson-Learning. Terjemahan

Fatihuddin, Didin, 2012, Metode Penelitian Untuk Ilmu Ekonomi, Manajemen dan Akuntansi dari Teori ke Praktek. Surabaya: Penebit PPS UMSurabaya

Firmansyah, M. A., \& Mahardhika, B. W. (2015). PENGARUH STRATEGI MARKETING MIX (PRODUK, HARGA, PROMOSI DAN DISTRIBUSI) TERHADAP KEPUTUSAN PEMBELIAN KONSUMEN BATIK DI SURABAYA. Balance, 12(02).

Ferdinand, A. (2002). Pengembangan Minat Beli Merek Eksistensi. Semarang: Badan Penerbit Universitas Diponegoro

Haryono T. (2012). Manajemen Promosi. Surakarta: UNS Pers

Hermawan, A. (2012). Komunikasi Pemasaran. Surabaya, Erlangga

Ghozali, Imam. (2013). Aplikasi Analisis Multivariat dengan SPSS, Cetakan keempat, Badan Penerbit Universitas Diponegoro, Semarang.

Hidayatullah, M., Fatihudin, D., \& Salbiyah, S. (2015). Implementasi Strategi Pemasaran Udang Vannamei Bagi Petani Tambak Di Desa Noreh Kecamatan Sreseh Kabupaten Sampang. Balance, 13(02).

Kotler, Philip dan Pe Gary, A, (1995). Dasar-dasar

Pemasaran, Penerbit Intermedia, Jakarta

Laksana, Fajar (2008). Manajemen Pemasaran, Penerbit Graha Ilmu, Yogyakarta

Lupiyoadi R. (2013). Manajemen Pemasaran Jasa. Berbasis Kompetensi, Jakarta: Salemba Empat

Oktavia P.A. (2016). Pengaruh Bauran Promosi Terhadap Minat Beli Konsumen MCDonald,s Cabang Rungkut Surabaya. Skripsi 
Suyoto, Danang, (2013). Teori, Kuesioner \& Analisis Data untuk Pemasaran dan Perilaku Konsumen(Pertama), Penerbit Graha Ilmu, Yogyakarta.

Wijaya David, (2012). Pemasaran Jasa Pendidikan. Penerbit Salemba Empat. Jakrta

Wijaya, Tony. (2012). Pemasaran Jasa. Jakarta: Salemba Empat.

Ferdinand, D. (2012). Pengembangan minat beli Merek Eksistensi. Semarang: Bandan Penerb Universitas Diponegoro.gn SPSS, Cetakan keempat. Bandan Peneribit Universitas Diponegoro, Semarang

Ratnasari R,T dan Mastuti. (2011). Manajemen Pemasaran Jasa, Teori dan Kasus. Surabaya, Ghalia Indonesia
Ruslan, R. (2008). Manajemen Public Relations \& Media Komunikasi, Konsepsi dan Aplikasi, Edisi Revsi Jakarta: Rajawali Pers

Riadi, E. (2016). Statistika Penelitian. Analisis Manual dan IBM SPSS.Yogyakarta: Penerbit. CV Andi Offset

Sopiah, Syihabudhin (2008). Manajemen Bisnis Ritel, Yogyakarta: C.V Andi Offset.

Tjiptono, Fandy. (2001). Strategi Pemasaran. Yogyakarta: Andi. Edisi ketiga, Cetakan kesatu

Tristatin, V. Dan Suwandi. (2013). "Pengaruh promotion Mix terhadap Minat Beli Konsumen di Family Fun Karaoke Keluarga". Hospitality dan Manajemn Jasa. Vol 2, No. 1, Halaman 419-429. 